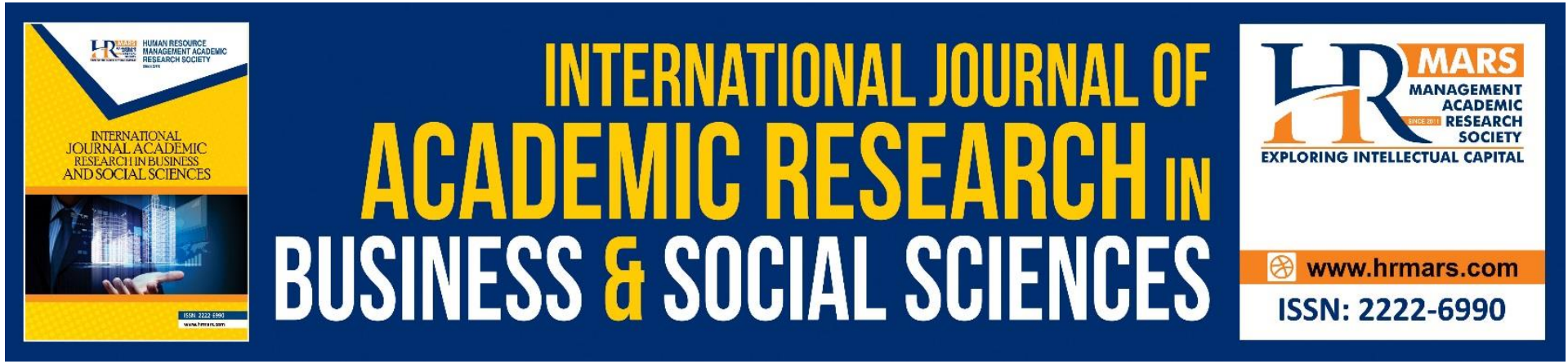

\title{
Constructing the Post COVID-19 Pandemic Psychoeducational Support Module for Public Healthcare Frontliners in Malaysia
}

\section{Abu Yazid Abu Bakar}

To Link this Article: http://dx.doi.org/10.6007/IJARBSS/v11-i7/10654

DOI:10.6007/IJARBSS/v11-i7/10654

Received: 11 May 2021, Revised: 18 June 2021, Accepted: 10 July 2021

Published Online: 27 July 2021

In-Text Citation: (Bakar, 2021)

To Cite this Article: Bakar, A. Y. A. (2021). Constructing the Post COVID-19 Pandemic Psychoeducational Support Module for Public Healthcare Frontliners in Malaysia. International Journal of Academic Research in Business and Social Sciences, 11(7), 1626-1631.

Copyright: @ 2021 The Author(s)

Published by Human Resource Management Academic Research Society (www.hrmars.com) This article is published under the Creative Commons Attribution (CC BY 4.0) license. Anyone may reproduce, distribute, translate and create derivative works of this article (for both commercial and non-commercial purposes), subject to full attribution to the original publication and authors. The full terms of this license may be seen at: http://creativecommons.org/licences/by/4.0/legalcode

Vol. 11, No. 7, 2021, Pg. 1626 - 1631

Full Terms \& Conditions of access and use can be found at http://hrmars.com/index.php/pages/detail/publication-ethics 


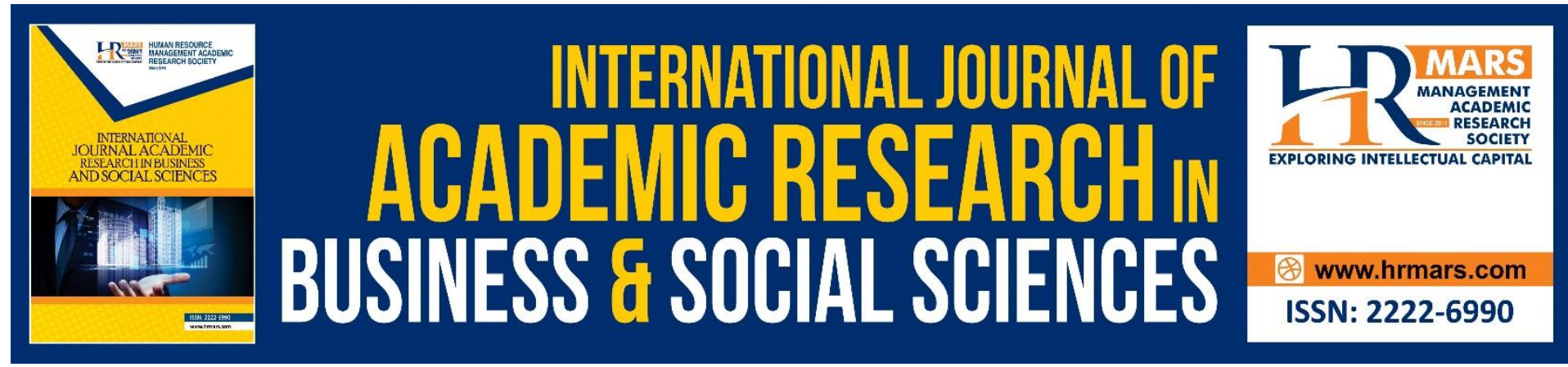

\title{
Constructing the Post COVID-19 Pandemic Psychoeducational Support Module for Public Healthcare Frontliners in Malaysia
}

\author{
Abu Yazid Abu Bakar \\ Faculty of Education, Universiti Kebangsaan Malaysia, 43600 Bangi, Selangor, MALAYSIA
}

\begin{abstract}
A holistic crisis management module encompasses thorough planning on strengthening the physical, mental, psychology, emotional, and social aspects for all parties involved albeit implicitly or explicitly. In Malaysia, the standard operating procedures (SOP) in handling natural disasters (like COVID-19) are predominantly centralized on solidifying the physical preparedness of the setbacks, rather than strengthening the soft skills of the frontliners involved. These frontliners who serve as the vital shields against the widespread of the pandemic must be systematically equipped with defense mechanism on how to counteract against destructive psychological effects such as excessive level of stress, overbearing depression, and traumatic experiences. Since COVID-19 pandemic affected the nation in March 2020, Malaysian public healthcare frontliners have been facing tremendous ups and downs in battling the virus, especially in the psychological and mental departments. Hence, this conceptual paper proposes the need to develop psychoeducational module to be used to train these frontliners in order to enhance their mental preparation so that it will maintain their psychological well-being.
\end{abstract}

Keywords: COVID-19, Healthcare, Module, Psychoeducational, Malaysia

\section{Introduction}

It is worth to note that the 2019 novel Coronavirus or COVID-19 pandemic is not the first plague to be faced by global healthcare practitioners in terms of dealing with situational crises involving high-scale infectious diseases. The world including Malaysia has had the experiences in managing many viral infections such as Severe Acute Respiratory Syndrome (SARS), Japanese Encephalitis (JE), influenza A H1N1, Ebola, and Zika (Abdullah \& Rahim, 2016; Kementerian Kesihatan Malaysia, 2016).

However, the COVID-19 pandemic scenario is vastly different for the natures of the cases are unprecedented and the spreading rate was extremely rapid from the time it was first discovered in Wuhan, China on December 2019 (Cuiyan et al., 2020). On 11 ${ }^{\text {th }}$ March 2020, the World Health Organization (WHO) gazetted COVID-19 as a situational health crisis pandemic defined as a global rapid widespread plague with the possibility of infecting large population of people and therefore requires systematic counteracting plans by every nation in the world to curb the pandemic (The Star, 2020). Consequently, those healthcare frontliners entrusted to manage the COVID-19 pandemic are to experience various types of mental health setbacks 
that are bound to jeopardize their own well-being as well as their professional preparedness to execute their responsibilities as the healthcare frontliners effectively (Bakar \& Ramli, 2020; Jianbo et al., 2020; Yanping et al., 2020; New Straits Times, 2020).

Historically, Malaysia has experienced several national calamities which demanded the nation to administer effective strategies on managing the crises such as scenarios that were related to geo-politics, natural disasters, and health fiascos such as infectious plagues. As a focal point in managing the crises, The Prime Minister's Department through its National Security Council (MKN) has issued several crises management strategies in 2012 meant to be as guidelines to counteract against national outbreaks.

On the other hand, the local authorities has issued specific counteract guidelines to be followed by all parties involving in managing local-based health fiascos (Kementerian Kesihatan Malaysia, 2016, 2013) and continually to be updated based on the national experiences in managing plagues such as Severe Acute Respiratory Syndrome (SARS), Japanese Encephalitis (JE), influenza A H1N1, Ebola, and Zika (Abdullah \& Rahim, 2016). Nevertheless, it should be noted that these crises management guidelines are considerably generic as the procedures for execution are still in vague. For instance, the Rule No.20 issued by National Security Council (MKN) merely highlights the role and function of Ministry of Health (MOH) during normal outbreaks while two other manuals issued by $\mathrm{MOH}$ in 2013 and 2016 also failed to specify any execution of special support systems when dealing with unprecedented crises.

\section{Discussion}

When COVID-19 pandemic surfaced, all the main players involved in the national crises management were struck with the unprecedented experience. However, swift and effective actions to curb the pandemic in Malaysia including to reinforce the control and prevent mechanisms (Bakar, 2020; Brooks, et al., 2020) has successfully led Malaysia to confine the widespread of the virus.

Nevertheless, it is worth to note that the healthcare frontliners entrusted to be the first shields against the widespread of this virus are actually the ones that are mostly affected during this trying time especially when their hours of duties are prolonged than the usual schedules. Although this article does not attempt to discredit the professionalism shown by these frontliners, it is essential to consider the challenges initiated by the work pressure they faced as now they have to work in unbalanced working schedules that are potential to exhaust the psychological, emotional, social and spiritual states bound to jeopardize the quality of their work and self-motivation.

Frontliners with that are equipped with holistic preparation on the aspects such as physical, mental, psychological, emotional, social and spiritual are bound to possess high motivation and working morale as well as to strengthen their spirits in facing the challenging circumstances during this health fiasco pandemic. Physical, skills and knowledge preparations ought to be supported with proactive psychosocial-emotional and spiritual managements in the form of continuous training that are constructed based on a comprehensive psychoeducational module that is scientifically verified and proven for its effectiveness.

In this vein, it is implied that all parties involved in the healthcare industry are unanimously agreeable that there is a critical need to create an integrated psychological support system to help these frontliners who are inevitably to be affected in long term (World Health Organization, 2020; British Columbia Ministry of Health, 2020; International Council of Nurses, 2020). In other words, the well-being of these frontliners are in grave jeopardy if they are still unequipped with holistic preparation for them to combat the pandemic and that 
include aspects such as mental, emotional, spiritual and self-social managements.

This psychoeducational module shall be constructed with the main objective to equip the frontliners with self-endurance and resilience which would form as proactive approach once they are to deal with circumstances involving health fiascos related to the pandemic in the future. Other objectives for the construction of this module are: This module would serve as a training platform to strengthen the psychological, emotional, social and spiritual aspects of the frontliners in order to encapsulate sense of comprehensive health aspects. Apart from that, it could also be a type of proactive intervention by being a pre-situational pandemic crisis stimulant and through this, frontliners would be able to familiarize and prepare themselves mentally, psychologically, emotionally, socially and spiritually for the upcoming challenges that are surely to push their limits.

Instruments such as General Health Questionnaire (GHQ), Personal Well-Being Questionnaire (PWQ), Brief Resilience Scale (BRS), dan Spiritual Needs Questionnaire (SNQ) will be used to collect basic data from frontliners that would be trained to use this module. Data will then be analysed by using Fuzzy Delphi method, descriptive and inferential approaches via Statistical Package for Social Sciences (SPSS) software version 23.0.

\section{Conclusion}

Although there are many types of interventions created since the triggering of COVID-19 pandemic due to the rising awareness that frontliners must be helped in balancing their psycho-social-emotional and spiritual aspects, it should be noted that all these services are reactive-in-nature and only materialize once crisis happens. In other words, there is yet to be any localized psychoeducational support module to combat pandemic crises such as COVID19. Therefore, it is evident that there is a significant need to create proactive support service that would be able to equip the healthcare frontliners with strong sense of self-motivation and resilience prior to any crises in the future.

It is vital that this module be integrated in future national training of healthcare frontliners so that they could be prepared not only physically and work knowledge/skill wise, but also in terms of mental health and psychological well-being preparedness. The holistic preparation of healthcare workforce in order to battle the pandemic scenario with many uncertainties and uncomfortable conditions, will prevent them from being disturbed by negative effects such as burnout, destructive stress or depression, and loss of job motivation/satisfaction. The implementation and application of this psychoeducational module would not only be confined for the healthcare frontliners but also towards those who are directly involved in any other crises or to those who are involved in managing the crises such as security teams, reinforcement teams, and many more.

All in all, the widespread of COVID-19 all over the world including Malaysia, has taught us to re-visit our national crisis management strategy - which put too much focus on the physical infrastructure preparedness before - by starting to pay more attention in the development of more stable and well-prepared workforce, particularly the healthcare frontliners who can be considered as the first line of defence during health crisis like the COVID-19 pandemic.

\section{Acknowledgements}

Authors are grateful to Faculty of Education, Universiti Kebangsaan Malaysia that had funded this study via an internal research grant (Code No.: GG-2020-023). 


\section{References}

Abdullah, N. A., \& Rahim, R. A. (2016). Infectious disease and bioterrrorism: Disaster to public health and security in Malaysia. Jurnal Undang-Undang dan Masyarakat, 20, 43-50.

Bakar, A. Y. A. (2020). Pentingnya sokongan psikososial mendepani krisis COVID-19. BERNAMA, 27 April, 1-2.

Bakar, A. Y. A., \& Ramli, S. (2020). Psychosocial support for healthcare frontliners during COVID-19 pandemic in Malaysia. Asian Journal of Psychiatry, 54, 102272, 1-2.

British Columbia Ministry of Health. (2020). Supporting the psychosocial well-being of health care providers during the Novel Coronavirus (COVID-19) pandemic. http://www.bccdc.ca/Health-Professionals-Site/Documents/COVID19-PsychosocialSupports-HCW.pdf. Retrieved 2 April.

Brooks, S. K., Webster, R. K., Smith, L. E., Woodland, L., Wessely, S., Greenberg, N., \& Rubin, G. J. (2020). The psychological impact of quarantine and how to reduce it: Rapid review of the evidence. The Lancet, 395, 912-920.

Cuiyan, W., Riyu, P., Xiaoyang, W., Yilin, T., Linkang, X., Cyrus, S. H., \& Roger, C. H. (2020). Immediate psychological responses and associated factors during the initial stage of the 2019 Coronavirus Disease (COVID-19) epidemic among the general population in China. Int. J. Environ. Res. Public Health, 17(5), 1-25.

International Council of Nurses. (2020). ICN COVID-19 Update: New guidance on mental health and psychosocial support will help to alleviate effects of stress on hard-pressed staff. https://www.icn.ch/news/icn-covid-19-update-new-guidance-mental-health-andpsychosocial-will-help-alleviate. Retrieved 2 April.

Jabatan Perdana Menteri. (2012). Arahan No. 20 (Semakan Semula): Dasar dan Mekanisme Pengurusan Bencana Negara. Putrajaya: Majlis Keselamatan Negara.

Jianbo, L., Simeng, M., Ying, W., Zhongxiang, C., Jianbo, H., Ning, W., Jiang, W., Hui D., Tingting, C., Ruiting, L., Huawei, T., Lijun, K, Lihua, Y., Manli, H., Huafen, W., Gaohua, W., Zhongchun, L, \& Shaohua, H. (2020). Factors associated with mental health outcomes among health care workers exposed to Coronavirus Disease 2019. JAMA Network Open, 3(3), 1-12.

Kementerian Kesihatan Malaysia. (2016). Malaysia Strategy for Emerging Diseases and Public Health Emergencies (MySED) II Workplan (2017-2021).

http://www.moh.gov.my/moh/resources/Penerbitan/Garis\%20Panduan/Pengurusan\% 20KE sihatan\%20\&\%20kawalan\%20pykit/MySED_II.pdf. Retrieved 2 April.

Kementerian Kesihatan Malaysia. (2013). Manual on Mental Health and Psychosocial Response to Disaster in Community.

http://www.moh.gov.my/index.php/dl/554756755a584a69615852686269394859584a 7063794251. Retrieved 2 April.

New Straits Times. (2020). Covid-19 and the mental health risks to frontliners. https://www.nst.com.my/news/nation/2020/03/578454/covid-19-and-mental-healthrisks-frontliners. Retrieved 2 April.

The Star. (2020). Covid-19: What to do when a pandemic is declared? https://www.thestar.com.my/lifestyle/health/2020/03/26/what-to-do-when-a pandemic-is-declared. Retrieved 2 April.

World Health Organization. (2020). Mental health and psychosocial considerations during the COVID-19 outbreak. https://www.who.int/docs/default-source/coronaviruse/mentalhealth-considerations.pdf. Retrieved 2 April.

Yanping, B., Yankun, S., Shiqiu, M., Jie, S., \& Lin, L. (2020). 2019-nCoV epidemic: Address 
INTERNATIONAL JOURNAL OF ACADEMIC RESEARCH IN BUSINESS AND SOCIAL SCIENCES Vol. 11, No. 7, 2021, E-ISSN: 2222-6990 @ 2021 HRMARS

mental health care to empower society. The Lancet, 395, 37-38. 